\title{
Some Reflections on the Right to Self-representation Before International Tribunals
}

\author{
Wolfgang Schomburg
}

C ERA 2011

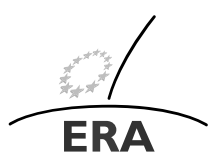

EUROPÄISCHE RECHTSAKADEMIE ACADEMY OF EUROPEAN LAW ACADEMIE DE DROIT EUROPEEN ACCADEMIA DI DIRITTO EUROPEO

TRIER - TREVES - TREVIRI

\begin{abstract}
The right to self-representation forms a part of the fair trial guarantees vital to every criminal proceeding. The accused, an individual human being, is to stand in the centre of his own trial, i.e. as a subject not an object of the proceedings. On the other hand, a fair trial also calls for the existence of equality of arms. As judicial procedures tend to be hard to grasp in their entirety for an accused not trained in a legal profession the right to self-representation has its barriers were the complexity of the case demands the accused to be assisted and/or represented by a counsel, even against his will. By the same token, where an accused due to his own behaviour obstructs the expeditious and effective carriage of the proceedings the interests of justice can necessitate the limitation or even the waiver of the right to self-representation. The difficulties to define and limit the right to self-representation in an adequate manner have been subject to a constant debate before the ad hoc Criminal Tribunals. The author highlights the cornerstones of this development thus illustrating the delicate balancing act between the conflicting interests involved.
\end{abstract}

Keywords Self-representation - International tribunal · Ad hoc criminal court · Fair trial

Wolfgang Schomburg was a Judge of the Appeals Chambers of the International Criminal Tribunals for the Former Yugoslavia and Rwanda. He was formerly a Senior Public Prosecutor and Judge in Berlin, a Judge of the German Federal Supreme Court (Bundesgerichtshof), and Under-Secretary of State (Staatssekretär) in the Berlin Department of Justice. At present he serves as member of the Board of Trustees of ERA.

Professor W. Schomburg ( $\varangle)$

FPS Rechtsanwälte und Notare, Berlin, Germany

e-mail: intjuscrim.schomburg@gmx.net 


\section{The Applicable Law}

\subsection{Article $14(3)$ of the ICCPR ${ }^{1}$}

"In the determination of any criminal charge against him, everyone shall be entitled to the following minimum guarantees, in full equality:

(d) To be tried in his presence, and to defend himself in person or through legal assistance of his own choosing; to be informed, if he does not have legal assistance, of this right; and to have legal assistance assigned to him, in any case where the interests of justice so require, and without payment by him in any such case if he does not have sufficient means to pay for it;,"2

\subsection{Article 6(3) of the $\mathrm{ECHR}^{3}$}

"Everyone charged with a criminal offence has the following minimum rights: ...

(3) to defend himself in person or through legal assistance of his own choosing or, if he has not sufficient means to pay for legal assistance, to be given it free when the interests of justice so require;"

\section{The Law Applied}

The right to be assisted by counsel is "paramount to the concept of due process," since it is a guarantee of protection from being arbitrarily arrested, charged or prosecuted. The right to self-representation has been addressed in the jurisprudence of the ad hoc International Criminal Tribunals, the ICTY ${ }^{4}$ and the ICTR, ${ }^{5}$ from their establishment onwards. It is the intention of the author here to focus primarily on the ongoing struggle to define that right. As this analysis will show, the ICTY's conception of the right to self-representation has undergone several shifts, from an absolute right facilitated by an amicus curiae, to a right facilitated by standby counsel, to a right facilitated by counsel imposed in the interest of justice, to an absolute right to pretend to defend oneself, and finally to a right to pretend to defend oneself while assisted both by counsel behind the scenes and by counsel in court accompanied by

\footnotetext{
${ }^{1}$ International Covenant on Civil and Political Rights, Dec. 16, 1966, 999 U.N.T.S. 171 [hereinafter ICCPR].

${ }^{2}$ Cf. also African Charter on Human and People's Rights June 27, 1981, 21 I.L.M. 58 [hereinafter ACHPR] Art. 7(1)(c); American Convention on Human Rights Nov. 22, 1969, 1144 U.N.T.S. 123 [hereinafter ACHR], Art. 8(2)(d); Statute of the International Criminal Tribunal for the former Yugoslavia, May 25, 1993, 32 I.L.M. 1192 [hereinafter ICTY Statute], art. 21(1)(d); Statute of the International Criminal Tribunal for Rwanda, Nov. 8, 1994, 33 I.L.M. 1598 [hereinafter ICTR Statute], Art. 20(1)(d).

${ }^{3}$ Convention for the Protection of Human Rights and Fundamental Freedoms, Nov. 4, 1950, CETS No. 005 [hereinafter ECHR].

${ }^{4}$ International Criminal Tribunal for the former Yugoslavia.

${ }^{5}$ International Criminal Tribunal for Rwanda.
} 
an amicus curiae. ${ }^{6}$ The deplorable effect to the effectiveness and fairness of proceedings before the first ad hoc Criminal Tribunals calls for an in-depth discussion of this topic.

Before taking a look at the history of self-representation within the UN ad hoc International Tribunals, it is necessary to understand what motivates an accused party to defend himself, given the conventional wisdom "that a lawyer who represents himself has a fool for a client." ${ }^{7}$ Unlike in civil law systems, where the accused is entitled to intervene in the trial proceedings whenever he deems it necessary, in common law systems, and as is practiced before the ICTY, the accused does not enjoy this right. Instead, he becomes the mere object of his own proceedings as soon as he decides to be represented by counsel. His only opportunity to address the court directly is to give testimony on his own behalf. It is therefore not surprising that the right to selfrepresentation is often given high priority before courts e.g. in the United States of America. ${ }^{8}$

Given that the proceedings at the ICTY and the ICTR are driven by an adversarial model rather than an inquisitorial model, parties have to make a decision to either play an active part in the proceedings or not. However, as M. Cherif Bassiouni rightly observes, "representation of counsel is not only a matter of interest to the accused, but is also paramount to due process of the law and to the integrity of the judicial process." Consequently, it is critical for the court to ensure the adequacy and effectiveness of self-representation. ${ }^{9}$ Moreover, whenever the court deems it to be in the interest of justice and in the interest of providing for effective representation of the accused, it must assign counsel to him, of his own choosing, if possible. The disjunction of "selfrepresentation or counsel" in Article 14(3)(d) of the ICCPR was never meant to be understood as a dichotomy. ${ }^{10}$ Instead, "the right to defence ensures that the accused has an active role in the proceedings, the role of a subject rather than an object."11 Based on a sound interpretation of the word "or" in Article 14(3)(d) of the ICCPR has to be replaced by the word "and", thus reflecting the proper approach to a holistic understanding of "defence" forming part of the fair trial guarantee.

In 2004, the Appeals Chamber in S. Milošević addressed the issue of selfrepresentation for the first time in more general terms. The Appeals Chamber,

\footnotetext{
${ }^{6}$ See, e.g., the appellate proceedings in Prosecutor v. Momčilo Krajišnik, Case No. IT-00-39-A, Appeals Judgment, I[ 15 (Mar. 17, 2009).

${ }^{7}$ See generally Jørgensen [1], p. 711, pp. 711-726.

${ }^{8}$ As was illustratively put by the Court of Appeals for the Ninth Circuit in the recent case of United States v. Johnson et al., D.C. No. 3:05-cr-00611-WHA (July 6, 2010): "The defendants' courtroom behaviour, although eccentric at times, would not have justified, let alone required, the involuntary deprivation of their constitutional right to represent themselves." The court went on to state that "they were clearly fully competent, albeit foolish, to represent themselves" concluding that "[i]n the absence of any mental illness or uncontrollable behaviour, they had the right to present their unorthodox defences and argue their theories to the bitter end."

${ }^{9} I d$.

${ }^{10}$ Emphasis (italics) added by the author. Regarding the (rather confusing) use of disjunctions in international law see, e.g., Prosecutor v. Katanga \& Ngudjolo, Case No. ICC-01/04-01/07, Decision on the Confirmation of Charges, II 491 (Sept. 30, 2008).

${ }^{11}$ Trechsel [4], p. 247.
} 
though it affirmed the Trial Chamber's decision and agreed that the right to selfrepresentation was not absolute, limited the basis upon which counsel may be assigned to the accused. ${ }^{12}$ Because it considered "the right to self-representation [to be] an indispensable cornerstone of justice," the Appeals Chamber concluded that "any restrictions on Milošević's right to represent himself must be limited to the minimum extent necessary to protect the International Tribunal's interest in assuring a reasonably expeditious trial." 13 Hence, the Appeals Chamber allowed Milošević to represent himself, as long as he was "physically capable of doing so."14

The Trial Chamber had ordered the assignment of amici curiae to assist the court in the proper determination of the case, ${ }^{15}$ but the Appeals Chamber altered their role from friends of the court to friends of a party to the proceedings. In its "Decision on Appeal by Amici Curiae," the Appeals Chamber confronted the question of whether amici curiae may appeal decisions or judgments even though Rule 73 of the ICTY Rules $^{16}$ entitles only parties to the case to bring an appeal. Despite affirming that the status of amici curiae is not tantamount to that of parties, the Appeals Chamber decided to consider the appeal brought by the amici curiae, due to the "identity of interests between the amici and the accused with respect to the issue presented in this appeal" and the fact that Milošević's interests were not infringed. ${ }^{17}$ In his separate opinion, Judge Shahabuddeen stressed that the Appeals Chamber had illegitimately modified the role of an amicus curiae and that "under the system of the Tribunal, he is not legally competent to act as counsel for the accused, and he certainly is not an intervener." 18 In sum, the misuse of amicus curiae as a kind of mediator between the bench and the accused has proven to be a fundamental mistake. The true purpose of amici curiae is to submit arguments of states or others who do not have standing at trial, but nevertheless want the judges to hear their perspective. Amici curiae cannot serve both as pseudo-counsel for an accused pursuant to Article 14(3)(d) of the ICCPR and as pseudo-assistants to the bench. The conflict of interests in such circumstances is blatantly obvious.

Another Trial Chamber adopted a different approach in Šešelj. Due to the complexity of the case and the risk that Šešelj might harm the International Tribunal by using the trial as a platform for political interests and by showing disruptive behaviour, the Trial Chamber appointed a "standby counsel". ${ }^{19}$ Some of his responsibil-

\footnotetext{
${ }^{12}$ Milošević v. Prosecutor, Case No. IT-02-54-AR73.7, Decision on Interlocutory Appeal of the Trial Chamber's Decision on the Assignment of Defense Counsel, II 19 (Nov. 1, 2004).

${ }^{13}$ Id. II $11,17$.

${ }^{14}$ Id. II 19.

${ }^{15}$ Prosecutor v. Milošević, Case No. IT-02-54, Order Inviting Designation of Amicus Curiae (Aug. 30, 2001); Prosecutor v. Milošević, Case No. IT-02-54, Order Concerning Amici Curiae (Jan. 11, 2002).

${ }^{16}$ Rules of Procedure and Evidence, International Criminal Tribunal for the former Yugoslavia, Dec. 13, 2001, T/32/REV.22 [hereinafter ICTR Rules].

${ }^{17}$ Prosecutor v. Milošević, Case No. IT-02-4-AR73.6, Decision on the Interlocutory Appeal by the Amici Curiae Against the Trial Chamber Order Concerning the Presentation and Preparation of the Defence Case, II 4 (Jan. 20, 2004).

${ }^{18}$ Id. 15 (Judge Shahabuddeen, separately concurring).

${ }^{19}$ Prosecutor v. Šešelj, Case No. IT-03-67-PT, Prosecution's Motion for Order Appointing Counsel to Assist Vojislav Šešelj with his Defence, II 30 (May 9, 2003); Prosecutor v. Šešelj, Case No. IT-03-67-
} 
ities were to assist the accused in the preparation and presentation of the case whenever he requested to participate in the proceedings and to take over the defence from the accused whenever he was to be removed from the courtroom pursuant to Rule 80(B) of the ICTY Rules. ${ }^{20}$ The Trial Chamber granted him access to all court documents, including confidential materials. ${ }^{21}$ However, the Trial Chamber emphasised that "the accused's right to defend himself is absolutely untouched and that standby counsel is not an amicus curiae." 22 Additionally, the court distanced itself from the Trial Chamber in S. Milošević by declaring that "[i]t would be a misunderstanding of the word 'or' in the phrase 'to defend himself in person or through legal assistance of his own choosing' to conclude that self-representation excludes the appointment of counsel to assist the accused or vice versa." ${ }^{23}$ The advantage of a standby counsel is that he might deter the accused from engaging in obstructive behaviour, because the standby counsel's presence would ensure that his conduct would not lead to a delay of the proceedings. ${ }^{24}$

In response to Šešelj's obstructive behaviour, the Trial Chamber assigned him counsel in August 2006. ${ }^{25}$ However, the Appeals Chamber reversed that decision because the Trial Chamber had failed to issue a formal warning to $\breve{S} e \check{e}$ elj prior to assigning counsel. ${ }^{26}$ In November 2006, the Trial Chamber once again assigned counsel to Šešlj, who had been on a hunger strike. ${ }^{27}$ The Appeals Chamber was in the delicate position of reacting to Šešelj's deteriorating health while trying to uphold the integrity of the International Tribunal. ${ }^{28}$ In December 2006, the Appeals Chamber not only reversed the assignment of counsel to Šešelj but also ordered the Trial Chamber not to impose standby counsel "unless Šešelj exhibits obstructionist behaviour fully satisfying the Trial Chamber that, in order to ensure a fair and expeditious trial, Šešelj requires the assistance of standby counsel." ${ }^{29}$ Hence, the Appeals Chamber restored the full right to self-representation. ${ }^{30}$ The situation deteriorated as another judge ordered the ICTY to pay Šešelj's defence expenses with the International Tribunal's

PT, Decision on Prosecution's Motion for Order Appointing Counsel to Assist Vojislav Šešelj with his Defence, II 27 (May 9, 2003).

${ }^{20}$ Id. II 30.

${ }^{21}$ Prosecutor v. Šešelj, Case No. IT-03-67-PT, Decision on Prosecution's Motion for Order of NonDisclosure, IIII 2-3 (Mar. 13, 2003).

${ }^{22}$ Id. II 28.

${ }^{23}$ Id. II 29.

${ }^{24}$ See Scharf [2], p. 155, p. 167.

${ }^{25}$ Prosecutor v. Šešelj, Case No. IT-03-67-PT, Decision on Assignment of Counsel, II 79 (Aug. 21, 2006).

${ }^{26}$ Prosecutor v. Šě̌elj, Case No. IT-03-67-AR73.3, Decision on Appeal against the Trial Chamber's Decision on Assignment of Counsel, II 52 (Oct. 20, 2006).

${ }^{27}$ Prosecutorv. Šešelj, Case No. IT-03-67-T, Decision on Assignment of Counsel, II 81 (Nov. 27, 2006).

${ }^{28}$ It appears, however, that it did not succeed in doing so. See Alexander Zahar, Legal Aid, SelfRepresentation, and the Crisis at the Hague Tribunal, 19 Crim. L. F. 241 (2008); see also Sluiter [3], p. 529.

${ }^{29}$ Prosecutor v. Šešelj, Case No. IT-03-67-AR73.4, Decision on Appeal against the Trial Chamber's Decision (No. 2) on Assignment of Counsel, II 28 (Dec. 8, 2006).

${ }^{30}$ Id. II 30 . 
legal aid budget, even though the Registrar argued that only indigent accused parties are entitled to such assistance. This development led to the absurd situation in the ICTY, in which an accused party represents himself, but counsel in the background, presumably paid for in part by taxpayers worldwide, assist him. ${ }^{31}$

Scholars and practitioners have criticised the Appeals Chamber decision as being of "lamentable quality, as it distorts the law in an effort to achieve the desired result." 32 Some have suggested that the Appeals Chamber decision was a betrayal of the Trial Chamber's effort to conduct the trial in an optimal manner and that $\breve{S} e s ̌ e l j$ had finally succeeded in playing the Appeals Chamber against the Trial Chamber. ${ }^{33}$

In May 2007, in Krajišnik, the question was whether a convicted person can represent himself on appeal. The Appeals Chamber ruled in the affirmative, stating, "Article 21(4)(d) of the Statute draws no distinction between the trial stage and the appeal stage of a case [...] there is no obvious reason why self-representation at trial is so different in character from self-representation on appeal as to require an a priori distinction between the two." 34

The ICTR adopted a far more stringent position on the assignment of counsel as early as 2003. This position is mirrored in Rule 45quater of the ICTR Rules. ${ }^{35}$ The ICTY amended its Rules only in November 2008 by verbatim repeating the wording of the ICTR. Rule 45quater of the ICTR Rules and 45ter of the ICTY Rules now read as follows: "The Trial Chamber may, if it decides that it is in the interest of justice, instruct the Registrar to assign counsel to represent the interests of the accused." The aim is to obtain efficient representation and adversarial proceedings." 36 Ideally, counsel and accused act, both actively, together in perfect harmony.

In this context it has, in all fairness, to be recalled that not only the ICTY has problems to correctly apply the right of self-representation. The case of Correia de Matos v. Portugal was dealt before two different human rights institutions, the ECtHR and the UN HRComm ending in conclusions as different as chalk and cheese. Without going into any further details: the former rejected the application inadmissible as manifestly ill-founded, while the latter found a violation of Article 14(3)(d) of the ICCPR.

\footnotetext{
${ }^{31}$ Zahar, supra note 28, III 245-248.

${ }^{32}$ Sluiter, supra note 28 , I[ 531.

${ }^{33}$ Zahar, supra note 28, III 260-261; Sluiter, supra note 28, III 531-535.

${ }^{34}$ Prosecutor v. Krajišnik, Case No. IT-00-39-A, II 11 (Judge Shahabuddeen, concurring). However, a dissenting opinion argued: "The expeditiousness and fairness of the proceedings are intertwined. Therefore, when deciding whether the right to self-representation can be limited or qualified in appellate proceedings, it must be assessed whether such a step would benefit an appellant by ensuring his fundamental right to be the subject, not the object, of a fair and expeditious appeals process. An accused cannot waive his right to fair proceedings, under whatever circumstances," Prosecutor v. Krajišnik, Case No. IT-00-39-A, II 68, (Judge Schomburg, dissenting).

${ }^{35}$ Rules of Procedure and Evidence, International Criminal Tribunal for Rwanda, June 29, 1995, ITR/3/REV.1 [hereinafter ICTR Rules].

${ }^{36}$ Id. II 21. In this regard, note the separately concurring opinion of Judge Gunawardana, who went a step further and considered that art. 20(4)(d) of the ICTR Statute envisioned the appointment of standby counsel. ICTR Statute, supra note 2, art. 20(4)(d). See also Wald (Former President of ICTY) [5], pp. 37-46, pp. 51-58 and pp. 61-62.
} 
To cut this never ending story before the ICTY short: Radovan Karadžić continues to represent himself assisted by an amicus curiae defence team of his choosing. ${ }^{37}$ In addition, a stand-by counsel appointed by the Registrar of the Tribunal and paid by the international tax-payer attends the proceedings remaining in the background available to step in at any time deemed necessary by the Chamber. ${ }^{38}$ In case Karadžić should continue to absent himself from the trial proceedings or engage in any other conduct that obstructs the proper and expeditious conduct of the trial, he would forfeit his right to self-representation, no longer be entitled to assistance from his defence team, and the stand-by counsel would take over as an assigned counsel to represent him. ${ }^{39}$ An appalling scene.

My conclusion is that the overly doctrinal approach to permitting self-representation must yield to the fundamental right to a fair, public, and expeditious trial. Before International Tribunals, dealing with extraordinarily difficult cases only, assistance of a highly qualified counsel is a must. Nonetheless, the accused's right to participate actively in the proceedings (i.e., to defend himself or herself) must be protected. ${ }^{40}$ Joint efforts of accused and counsel are feasible and finally serve best the interests of justice and the accused.

\section{References}

1. Jørgensen, N.H.B.: The Right of the Accused to Self-representation before International Criminal Tribunals, 98 Am. J. Int'1 L. (2004)

2. Scharf, M.P.: Chaos in the Courtroom: Controlling Disruptive Defendants and Contumacious Counsel in War Crimes Trials, 39 Case W. Res. J. Int'l L. (2006)

3. Sluiter, G.: Comprising the Authority of International Criminal Justice: How Vojislav Šešelj Run His Trial, 5 J. Int'l Crim. Just. (2007)

4. Trechsel, S.: Human Rights in Criminal Proceedings (2005)

5. Wald, P.: Tyrants at Trial, Keeping order in the Courtroom, Open Society Institute, New York (2009)

${ }^{37}$ Prosecutor v. Karadžić, Case No. IT-95-5/18-T, Decision on Designation of Standby Counsel, II 8 (Apr. 15, 2010).

${ }^{38}$ Prosecutor v. Karadžić, Case No. IT-95-5/18-T, Registrar's Decision (Nov. 19, 2009).

${ }^{39}$ Prosecutor v. Karadžić, Case No. IT-95-5/18-T, Decision on Appointment of Counsel and Order on Further Trial Proceedings, p. II 27 (Nov. 5, 2009).

${ }^{40}$ It must be noted that the most recent and, consequently, developed standard is found in the Rules of Procedure and Evidence of the Special Tribunal for Lebanon. "A suspect or an accused electing to conduct his own defence shall so notify, in writing, the Pre-Trial Judge or a Chamber of his election. The Pre-Trial Judge or a Chamber may impose counsel to represent or otherwise assist the accused in accordance with international criminal law and international human rights where this is deemed necessary in the interests of justice and to ensure a fair and expeditious trial." Rules of Procedure and Evidence, Special Tribunal for Lebanon, Rule 59(F), STL/BD/2009/01/Rev. 1 (June 10, 2009). 